\title{
Exotic invertebrate species on offshore oil platforms
}

\author{
Henry M. Page* ${ }^{*}$ Jenifer E. Dugan, Carolynn S. Culver, Justin C. Hoesterey
}

Marine Science Institute, University of California at Santa Barbara, Santa Barbara, California 93106, USA

\begin{abstract}
We report the presence of 3 exotic invertebrate species inhabiting offshore oil and gas platforms on the Pacific offshore continental shelf (POCS) of central and southern California, USA. These exotic species occur in high cover or density and may negatively affect populations of native species on the platforms. Conspicuous exotic species (the bryozoan Watersipora?subtorquata and the anemone Diadumene sp.) were detected on 2 of 7 platforms surveyed. An inconspicuous exotic species (the amphipod Caprella mutica) was detected on 2 of 2 platforms surveyed for such smaller species. In addition to serving as a potential source of exotic species to natural reef habitats, the presence of exotic species on oil platforms may influence the degree to which these structures provide the ecological services of natural reefs. The presence of exotic species on platforms also has consequences for various platform decommissioning options in California and elsewhere (there are an estimated 7000 offshore platforms/installations worldwide), including the removal and transport of platforms for use as artificial reefs, if removals are conducted without regard for the potential transport/dispersal of these species. Further knowledge of the identity of exotic species on oil platforms, their potential for dispersal and interaction with native species, and whether these species can also occur on artificial reefs, will improve our understanding of the effects that artificial structures in general have on the ecological functioning of coastal ecosystems.
\end{abstract}

KEY WORDS: Offshore oil platforms · Artificial structure · Exotic species · Caprella mutica · Watersipora ?subtorquata - Diadumene sp.

\section{INTRODUCTION}

The invasion and spread of exotic plant and animal species is considered one of the greatest threats to biological diversity and the functioning of aquatic ecosystems today (Schmitz \& Simberloff 1997, Bax et al. 2003). Exotic species can reduce the number and abundance of native species, alter the structure of native habitat, and negatively affect ecosystem processes (Grosholz 2002). Artificial structures, such as ships (hulls, ballast tanks), and aquaculture facilities serve as vectors for the dispersal of exotic species in the marine environment by providing habitat or facilitating the transport of these species (Carlton 1987, 1992).

It has been suggested that offshore oil and gas platforms could facilitate species range expansions and/or the introduction of exotic species into new geographic areas by serving as 'stepping stones' of vertical relief and hard substrate habitat across a soft seafloor environment (Gallaway \& Lewbel 1981). Offshore oil and gas platforms are among the largest artificial structures in the marine environment. Worldwide, there are close to 7000 offshore oil and gas platforms/installations (Hamzah 2003). Of these, 27 are located on the Pacific offshore continental shelf (POCS) of central and southern California, USA (Schroeder \& Love 2004). Attached to the submerged portions of these platforms are assemblages of invertebrate species typically found on shallow natural reefs and pier pilings (e.g. mussel Mytilus californianus, gooseneck barnacle Pollicipes polymerus, strawberry anemone Corynactis californicus) as well as other species that are relatively rare in the nearshore environment (e.g. plumed anemones Metridium spp.) (Wolfson et al. 1979, Page et al. 1999).

To date, there are few published reports of exotic species on oil platforms. Notably, an exotic coral species, Tubastraea coccinea, was reported to be abun- 
dant, along with native coral species, on platforms within $15 \mathrm{~km}$ of the coral populations of the Flower Garden Banks in the Gulf of Mexico (Sammarco et al. 2004). Observations by other researchers also suggest that platforms in the Gulf of Mexico have facilitated the arrival of several new species of fishes at the Flower Garden Banks by providing a recruitment habitat for juveniles (Pattengill et al. 1997, Rooker et al. 1997).

We report here the presence of populations of exotic invertebrate species at 4 POCS oil and gas platforms. These exotic species occur in high percentage cover or density and may negatively affect native species on the platforms, but have not yet been reported either as present or occurring in comparable densities on natural subtidal rocky reefs inshore of these platforms.

\section{MATERIALS AND METHODS}

The platforms studied here are arrayed geographically in the Santa Barbara Channel, California, 2.9 to $16.9 \mathrm{~km}$ offshore, from the southeast near the city of Oxnard, to the northwest towards Point Conception, in water depths ranging from 29 to $225 \mathrm{~m}$ (Table 1, Fig. 1a). The platforms differ in size, but their general configuration is similar, with the subtidal portion consisting of vertical, oblique, and horizontal cross members together with conductor pipes through which the wells are drilled. The platforms were chosen based on accessibility (some have restricted access), broad spatial coverage (65 km of the Santa Barbara Channel), and proximity to natural reefs.

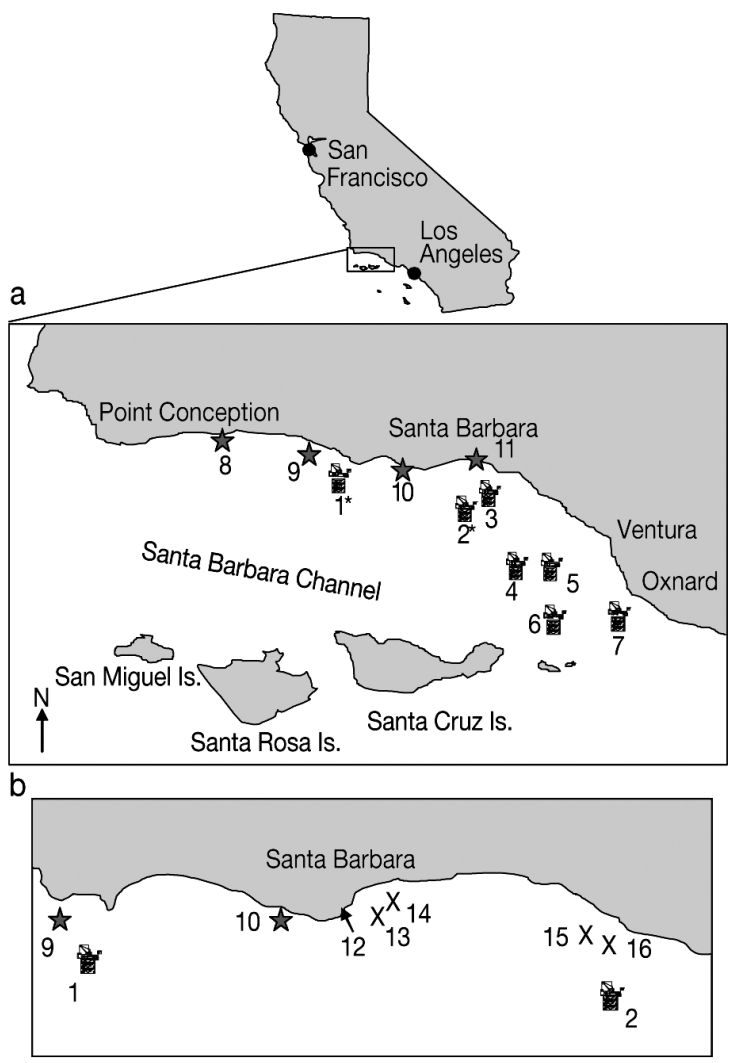

Fig. 1. (a) Relative locations of oil and gas platforms ( 1 to 7) and natural reef study sites ( 23,8 to 11) in Santa Barbara Channel; 1: Holly, 2: Houchin, 3: Hogan, 4: Grace, 5: Gilda, 6: Gail, 7: Gina; 8: Arroyo Quemado, 9: Naples, 10: Mohawk, 11: Carpinteria. (b) Detailed view of sites sampled for inconspicuous species; $(X)$ buoy lines at (15 and 16) former sites of Platforms Hazel and Hilda and (13 and 14) $2 \mathrm{~km}$ outside mouth of Santa Barbara Harbor (12)
Table 1. Offshore platforms surveyed in this study. Offshore: distance from shore, Depth: water depth, Age: age up to 2005, Jacket: bottom area of platform jacket, Consp., Inconsp.: conspicuous and inconspicuous exotic species, respectively, +: detected, -: not detected in samples, ns: not surveyed. Platform details from Love et al. (2003)

\begin{tabular}{|c|c|c|c|c|c|c|c|}
\hline \multicolumn{2}{|l|}{ Platform } & \multirow{3}{*}{$\begin{array}{c}\begin{array}{c}\text { Offshore } \\
(\mathrm{km})\end{array} \\
6.0\end{array}$} & \multirow{3}{*}{$\begin{array}{c}\begin{array}{c}\text { Depth } \\
\text { (m) }\end{array} \\
29\end{array}$} & \multirow{3}{*}{$\begin{array}{c}\begin{array}{c}\text { Age } \\
(\mathrm{yr})\end{array} \\
25\end{array}$} & \multirow{3}{*}{$\begin{array}{c}\begin{array}{c}\text { Jacket } \\
\left(\mathrm{m}^{2}\right)\end{array} \\
560\end{array}$} & \multicolumn{2}{|c|}{ Exotic species } \\
\hline & & & & & & Consp. & Inconsp. \\
\hline Gina & $\begin{array}{l}\left(34^{\circ} 07^{\prime} \mathrm{N}\right. \\
\left.119^{\circ} 16^{\prime} \mathrm{W}\right)\end{array}$ & & & & & - & ns \\
\hline Gail & $\begin{array}{l}\left(34^{\circ} 07^{\prime} \mathrm{N}\right. \\
\left.119^{\circ} 24^{\prime} \mathrm{W}\right)\end{array}$ & 16.0 & 225 & 18 & 5400 & + & ns \\
\hline Gilda & $\begin{array}{l}\left(34^{\circ} 10^{\prime} \mathrm{N}\right. \\
\left.119^{\circ} 25^{\prime} \mathrm{W}\right)\end{array}$ & 14.2 & 64 & 24 & 2340 & + & ns \\
\hline Grace & $\begin{array}{l}\left(34^{\circ} 10^{\prime} \mathrm{N}\right. \\
\left.119^{\circ} 29^{\prime} \mathrm{W}\right)\end{array}$ & 16.9 & 97 & 25 & 3120 & - & $\mathrm{ns}$ \\
\hline Hogan & $\begin{array}{l}\left(34^{\circ} 20^{\prime} \mathrm{N}\right. \\
\left.119^{\circ} 32^{\prime} \mathrm{W}\right)\end{array}$ & 6.0 & 46 & 37 & 1444 & - & ns \\
\hline Houchin & $\begin{array}{l}\left(34^{\circ} 20^{\prime} \mathrm{N}\right. \\
\left.119^{\circ} 33^{\prime} \mathrm{W}\right)\end{array}$ & 6.6 & 49 & 36 & 1444 & - & + \\
\hline Holly & $\begin{array}{l}\left(34^{\circ} 22^{\prime} \mathrm{N}\right. \\
\left.119^{\circ} 52^{\prime} \mathrm{W}\right)\end{array}$ & 2.9 & 64 & 39 & 1728 & - & + \\
\hline
\end{tabular}

We photographically sampled conspicuous invertebrates on 7 platforms and used air lift vacuum methods to sample less conspicuous small invertebrates (e.g. amphipods) on 2 of these platforms. Photographic sampling of conspicuous members of the platform invertebrate community was conducted in summer 2002 using a Nikonos V 35 mm camera fitted with a $15 \mathrm{~mm}$ lens and 2 strobes that were mounted on a PVC frame designed to photograph $0.25 \mathrm{~m}^{2}$ quadrats. The distribution and abundance of species were measured by divers photographing a single quadrat located inside and outside the 4 large corner support legs and 4 randomly selected conductor pipes at depths of $6,9,18$, and $24 \mathrm{~m}$. A total of 128 quadrats were photographed per platform. 
In the laboratory, we identified and estimated the percentage cover of species within each photoquadrat using point-contact methods, whereby the photographic slide images were projected onto 100 randomly located points and the contacts recorded to the lowest possible taxonomic level. For the purposes of this study, only the top layer was counted, except in cases where a species obviously spread over the substratum forming a 'canopy', typical of some arborescent bryozoans and hydroids. Samples of suspected exotic species were returned to the laboratory for further identification. We also inspected monitoring data on invertebrates collected by the 'Santa Barbara Coastal Long-term Ecological Research Program' (SBC-LTER) at 4 natural rocky reefs (Arroyo Quemado, Naples, Mohawk, Carpinteria) from 2003 to 2005 for the presence of the conspicuous exotic species found on the oil platforms.

We sampled small, less conspicuous invertebrates at 2 of the platforms - Platform Holly, located $\sim 3 \mathrm{~km}$ offshore, and Platform Houchin, located $\sim 7 \mathrm{~km}$ offshore-and 2 natural, subtidal, rocky reef outcrops inshore of these platforms (Naples Reef and Mohawk Reef) as part of another study. Small invertebrates were sampled for detailed taxonomic study in December 2003 and April, June, and September 2004 by scraping and vacuuming twelve $20 \times 20 \mathrm{~cm}$ quadrats randomly placed along fixed transects at a depth of $\sim 9 \mathrm{~m}$ at each location. On return to the laboratory, small invertebrates were separated from the remainder of each sample, which commonly included turfforming algae and (from the platforms) mussels and other large macroinvertebrates.

We also sampled less conspicuous invertebrates on artificial structures (docks, buoy lines) at locations inshore of Platform Houchin in September 2005, including the Santa Barbara Harbor and nearby Stearns Wharf, 2 buoy lines located at the former sites of Platforms Hazel and Hilda (Bomkamp et al. 2004), and 2 buoy lines located outside Santa Barbara Harbor $\sim 1 \mathrm{~km}$ from the harbor mouth (Fig. 1b). Samples were taken at a depth of $9 \mathrm{~m}$ from the buoy lines. Small invertebrates in the vacuum samples were identified using descriptions of Smith \& Carlton (1975) and Blake et al. (1997). Exotic species were identified by $\mathrm{H}$. Chaney, Santa Barbara Museum of Natural History, D. Fautin, University of Kansas, and K. Willis, Scottish Marine Biological Laboratory.

\section{RESULTS AND DISCUSSION}

Conspicuous exotic species were detected on 2 of the 7 platforms surveyed. The foliose encrusting bryozoan Watersipora ?subtorquata (also known as W. cucullata and $W$. subovoidea, nomenclature herein follows Cohen \& Carlton 1995, Cohen et al. 2002), occurs on 1 platform (Gilda, Platform 5 in Fig. 1a), where it forms substantial colonies (mean cover of $41 \%$ at a depth of $6 \mathrm{~m}, 15 \mathrm{~cm}$ thick) (Fig. 2a). Percent cover of $W$. ?subtorquata decreased with increasing depth (Fig. 2a). This species has also been reported from several harbor sites in southern California, including Port of Hueneme, Channel Islands Harbor, and Santa Barbara Harbor, located $\sim 18,16$, and $39 \mathrm{~km}$, respectively, inshore of the invaded platform (A. N. Cohen 2005, available at: www.exoticsguide.org). Natural rocky reef outcrops are absent directly inshore of Platform Gilda; $W$. ?subtorquata has not been reported from natural reefs in the vicinity of Santa Barbara $>27 \mathrm{~km}$ to the northwest (SBC-LTER unpubl. data). The genus Watersipora is found worldwide, including other locations in California (Cohen \& Carlton 1995), and is considered a significant fouling genus in Australia, New Zealand and Japan because of its resistance to toxic antifouling paints used on the hulls of ships (Floerl et al. 2004).

A second conspicuous exotic species, the anemone Diadumene sp., was found only at Platform Gail, where it occurred in highest mean cover at a depth of $12 \mathrm{~m} \mathrm{(38 \% ,} \mathrm{Fig.} \mathrm{2b).} \mathrm{Species} \mathrm{identification} \mathrm{is} \mathrm{ongoing,}$ but this anemone represents a species not yet recorded from California. Platform Gail was the most isolated platform that we surveyed, lying $16 \mathrm{~km}$ offshore of Oxnard and $13 \mathrm{~km}$ from Anacapa Island in a water depth of $225 \mathrm{~m}$, with the nearest platform $\sim 6 \mathrm{~km}$ away. While 4 species of Diadumene have been found in

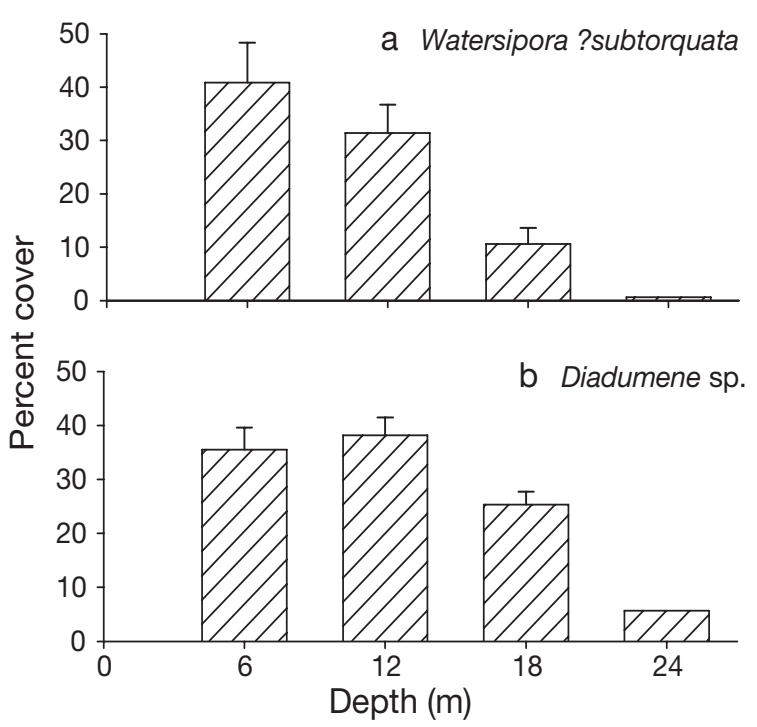

Fig. 2. (a) Watersipora ?subtorquata (bryozoan) and (b) Diadumene sp. (anemone) mean ( $\pm 1 \mathrm{SE})$ percent cover versus depth on Platforms Gilda and Gail 
other areas of California (Carlton 1979, Cohen \& Carlton 1995), only 1 species, D. franciscana, has been reported in southern California (Cohen \& Carlton 1995, Cohen et al. 2002). No species of Diadumene has been reported from natural inshore rocky reefs in the vicinity of Santa Barbara (SBC-LTER unpubl. data) or in the Northern Channel Islands (US National Park Service unpubl. data) despite long-term monitoring in these areas.

The distribution and abundance of the exotic bryozoan Watersipora ?subtorquata and the exotic anemone Diadumene sp. suggest that these species can preempt native species for space. Corynactis californicus is an abundant native species of anemone on platforms at the southeast end of the Santa Barbara Channel (C. S. Culver unpubl. data). However, on Platform Gilda, the cover of this anemone in photoquadrats was inversely related to the cover of the exotic bryozoan (Fig. 3a). On Platform Gail, C. californicus is not abundant and native sponges (e.g. Halichondria panicea) can occur in high cover; however, the cover of sponges
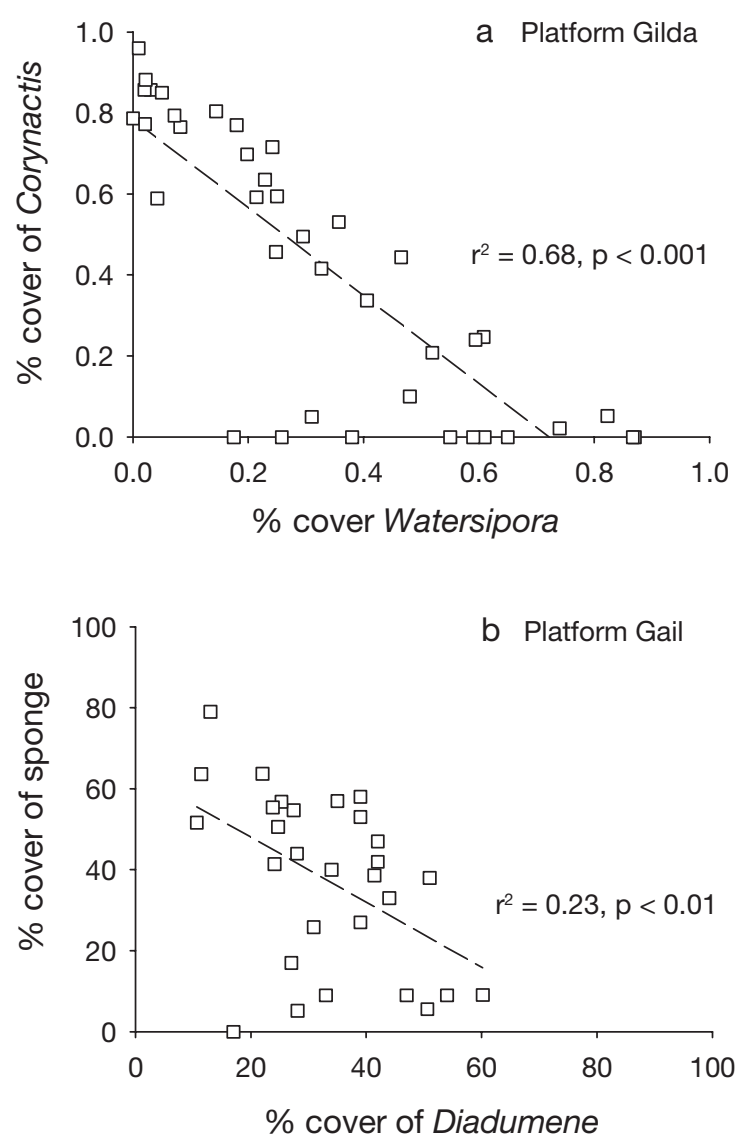

Fig. 3. Relationship between percent cover (a) of Watersipora ?subtorquata and native anemone Corynactis californica at Platform Gilda and (b) of Diadumene sp. and native sponge at Platform Gail in photoquadrats was inversely related to the cover of the exotic anemone (Fig. 3b). Although these correlative data suggest that the exotic bryozoan and anemone influence the distribution and abundance of native species on the platforms, further investigation is needed to test this hypothesis.

A third exotic species, the caprellid amphipod Caprella mutica, was present in the samples of less conspicuous invertebrates from Platforms Holly and Houchin, but absent or rare (only a few individuals found) in samples from natural reefs, sites of former platforms, and harbor sites (Fig. 4). C. mutica is a large caprellid (reaching $25 \mathrm{~mm}$ in length from base of Antenna I on head to 7 th pereonite in our samples) that has previously been reported from 4 harbor locations in southern California, including Port of Hueneme and Channel Islands harbors (Cohen et al. 2002), and also from other locations in California, including Humboldt Bay, Bodega Bay, San Francisco Bay, and Elkhorn Slough (Cohen \& Carlton 1995). C. mutica, indigenous to the coastal waters of NE Asia (Arimoto 1976), has also been recently reported from scattered locations in northern Europe, including Scotland (Willis et al. 2004), Ireland (Tierney et al. 2004), and Germany (Buschbaum \& Gutow 2005).

Densities of Caprella mutica on Platforms Holly and Houchin were much higher (several hundred individuals $400 \mathrm{~cm}^{-2}$ ) than densities of native caprellid species either on the platforms or on natural reefs (Fig. 5). The high densities of C. mutica at the platforms were similar to or exceeded those reported by Buschbaum \& Gutow (2005) for harbors at the islands of Sylt and Heligoland in the German Bight, North Sea. Species richness of native caprellids was lower on the 2 platforms (Holly 4 species, Houchin 3) than on the natural reefs (Naples 8 species, Mohawk 11) and overlapped values found on the other artificial structures sampled, Santa Barbara Harbor/Stearn's Wharf and the buoy lines (1 to 3 ) species each. The high densities of C. mutica on the platforms suggest that this species may adversely affect the abundance of native species. However, more detailed sampling is required, including acquiring information on microhabitat use by the exotic and native caprellid species, to evaluate the possibility that $C$. mutica preempts the native caprellid amphipods for space.

While the vector of dispersal of these species to the platforms is unknown, Watersipora spp. and Caprella mutica have been observed attached to the hulls of boats (Floerl et al. 2004, Willis et al. 2004, Buschbaum \& Gutow 2005); thus oil platform support boats or barges are a possible mode of initial introduction of these species to the platforms. Semisubmersible exploratory drilling platforms have also been reported to transport sea anemones as well 

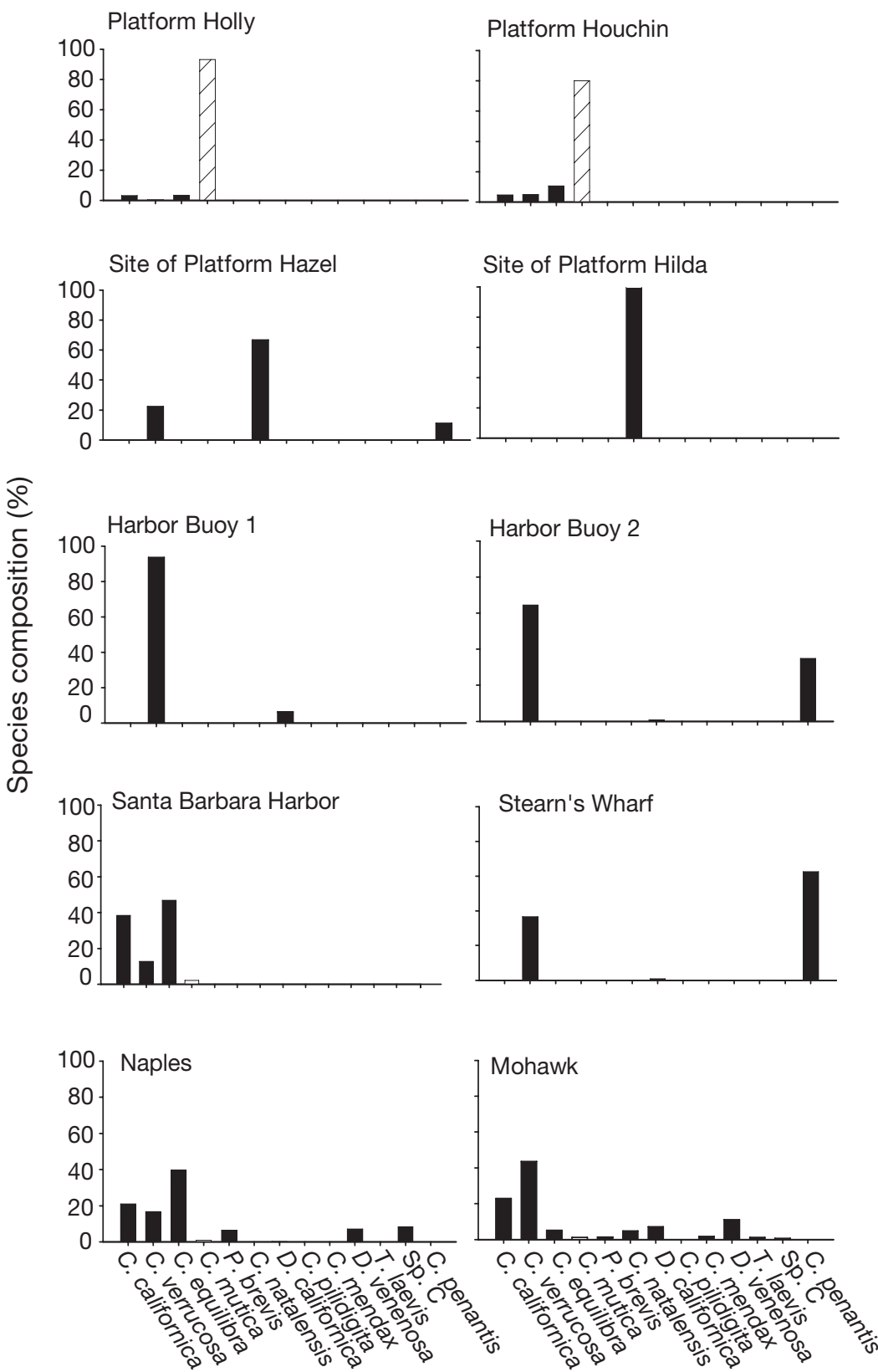

Fig. 4. Species composition of caprellid amphipods at platform, natural reef, harbor, and mooring-line sampling sites. Hatched bar: Caprella mutica; black bars: Caprella californica, C. verrucosa, C. equilibra, C. mutica, Perotripus brevis, C. natalensis, Deutella californica, C. pilidigita, C. mendax, D. venenosa, Tritella laevis, Sp. C (unknown), C. penantis

as other invertebrates, and thus are also a possible source of introduction of exotic species to the platforms (Carlton 1987). These structures are occasionally present in the Santa Barbara Channel and have been suggested as a vector of exotic species into the Gulf of Mexico (National Invasive species council, available at: www.invasivespeciesinfo.gov/ docs/council/mp.pdf).

\section{CONCLUSION}

In this preliminary survey, we found 3 exotic species on oil platforms in California. Of these platforms, 2 (Holly, Houchin) are located relatively close to inshore natural rocky reefs and harbors (within $3 \mathrm{~km}$ ). Either these exotic species have not been reported (Watersipora?subtorquata, Diadumene sp.), or they are present in extremely low abundance (Caprella mutica) on natural rocky reefs. Their potential to invade natural habitats and to become important space holders in these habitats is unknown. Of the 3 species, C. mutica may have the greatest potential to disperse in significant numbers to natural reefs. Although caprellid amphipods brood their young, juveniles and adults can become dislodged from the substratum and drift in the plankton (Smith 1977), often in association with drift macroalgae (Sano et al. 2003). In contrast, dispersal of $W$. ?subtorquata may be very limited, since this species has a planktonic larval duration of hours and no mobility of juvenile and adult stages (Wisely 1958). This species recruited to settlement plates attached to Platform Gilda, but not to plates at the other 6 platforms, including the nearest platform, Grace $(\sim 6.4 \mathrm{~km}$ distant) (C. S. Culver unpubl. data). Similarly, small individuals of the anemone Diadumene sp. were not observed on deployed settlement plates at platforms other than Platform Gail. These 2 species may depend more on mechanical transport via crewboats or barges for dispersal.

In evaluating the potential of these exotic species to disperse to natural reefs, it is interesting to note that $W a$ tersipora ?subtorquata, Caprella mutica, and species of Diadumene have been reported from some embayments and harbors (Cohen et al. 2002). Their occurrence on offshore platforms, which are located in an oceanic climate, suggests that the abiotic conditions of embayments are not required for the successful invasion of these species, and that abiotic factors per se will not limit their spread to natural reefs. In addition to propagule supply (discussed above), biotic processes, including competition and predation, may play a role 


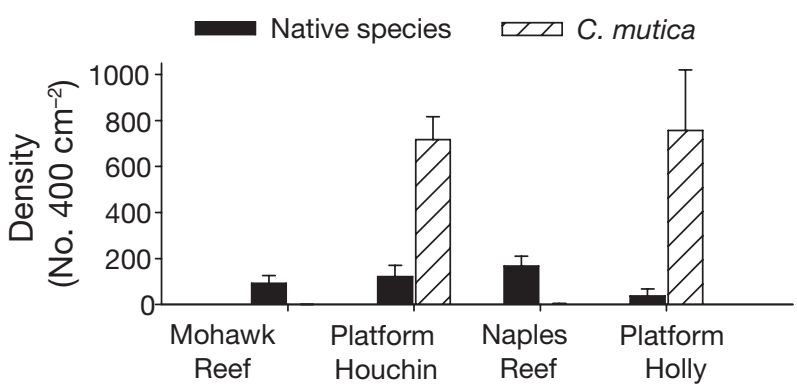

Fig. 5. Mean $( \pm 1 \mathrm{SE})$ density of native caprellid amphipods and of exotic species Caprella mutica in quadrat samples in December 2003, and April, June and September 2004 at Platforms Holly and Houchin, and at Naples and Mohawk Reefs

in limiting invasions into natural reefs. Coastal embayment and platform communities differ in species composition and abundance from those of nearshore rocky reefs and these differences may include the availability of potential competitors and predators that could influence the establishment of exotic species.

In addition to serving as a potential source of exotic species to natural habitats, the presence of exotic species on offshore platforms has implications for assessing the 'habitat value' of these structures and the degree to which offshore platforms (and artificial structures in general) provide the ecological services (e.g. biodiversity, habitat, food chain support) of natural inshore reefs. For example, a high density or cover of an exotic species may reduce the abundance of native species. On the other hand, caprellid amphipods are an important prey item in the diet of several reef fishes and the extremely high densities of the exotic caprellid may benefit some fish populations (H. M. Page unpubl. data).

Finally, the presence of exotic species has implications for platform 'decommissioning' in California and elsewhere. Several POCS platforms may be decommissioned in the coming years (Schroeder \& Love 2004), and the presence of exotic species has consequences for policy decisions concerning the fate of these structures. In particular, one decommissioning option used in the Gulf of Mexico involves the transport of platforms to other locations and deployment as artificial reefs in a 'rigs to reefs' program (Reggio 1989). In California, the spread of exotic species could be facilitated if this option were implemented for certain oil platforms. Removal of a portion or all of the structure under other alternative decommissioning options could also facilitate the dispersal of exotic species if removals are done haphazardly and without regard for the potential transport/dispersal of these species. Likewise, the transformation of oil platforms into large-scale mariculture operations (e.g. Grace Mariculture Project, California, Hubbs SeaWorld Research Institute, www. gracemaricultureproject.org) could result in the spread of these exotic species via fouled gear and animals. Further knowledge of the identity of exotic species on oil platforms, their potential for dispersal and interaction with native species, and whether these species can also occur on artificial reefs, will improve our understanding of the effects that artificial structures in general have on the ecological functioning of coastal ecosystems.

Acknowledgements. We thank all those who helped in the field and laboratory including (but not limited to) J. Bram, R. Fisher, A. Jensen, K. Johnston, B. Mardian, M. Newnham, J. Tarmann, and A. Willis. We also thank Venoco, Pacific Operators Offshore, and Nuevo Energy for access to their platforms. This work was supported by the Minerals Management Service, US Department of the Interior, the Coastal Marine Institute, University of California, Santa Barbara, and the Shoreline Preservation Fund and the Santa Barbara Coastal LTER through the National Science Foundation (OCE \#99-82105). The views and conclusions contained in this document are those of the authors and should not be interpreted as necessarily representing the official policies, either expressed or implied, of the US government.

\section{LITERATURE CITED}

Arimoto I (1976) Taxonomic studies of caprellids (Crustacea, Amphipoda, Caprellidae) found in the Japanese and adjacent waters. Spec Publ Seto Mar Biol Lab Ser III, p 1-229

Bax N, Williamson A, Aguero M, Gonzalez E, Geeves W (2003) Marine invasive alien species: a threat to global biodiversity. Mar Policy 27:313-323

Blake JA, Watling L, Scott PV (1997) Taxonomic atlas of the benthic fauna of the Santa Maria Basin and the Western Santa Barbara Channel, Vol 12. The Crustacea Part 3. The Amphipoda. Santa Barbara Museum of Natural History, Santa Barbara, CA

Bomkamp RE, Page HM, Dugan JE (2004) Role of food subsidies and habitat structure in influencing benthic communities of shell mounds at sites of existing and former offshore oil platforms. Mar Biol 146:210-211

Buschbaum C, Gutow L (2005) Mass occurrence of an introduced crustacean (Caprella cf. mutica) in the southeastern North Sea. Helgol Mar Res 59:252-253

Carlton JT (1979) Introduced invertebrates of San Francisco Bay. In: Conomos TJ (ed) San Francisco Bay: the urbanized estuary. Pacific Division, American Association for the Advancement of Science, San Francisco, CA, p 427-444

Carlton JT (1987) Patterns of transoceanic marine biological invasions in the Pacific Ocean. Bull Mar Sci 41:452-465

Carlton JT (1992) Dispersal of living organisms into aquatic ecosystems as mediated by aquaculture and fisheries activities. In: Rosenfield A, Mann R (eds) Dispersal of living organisms into aquatic ecosystems. Maryland Sea Grant, College Park, MD, p 13-46

Cohen AN, Carlton JT (1995) Nonindigenous aquatic species in a United States estuary: a case study of the biological invasions of the San Francisco Bay and Delta. (National Sea Grant College Program, Connecticut Sea Grant, NTIS Rep No. PB96-166525) US Fish \& Wildlife Service, Washington, DC

Cohen AN, Harris LH, Bingham BL, Carlton JT and 8 others (2002) Project report for the Southern California exotics 
expedition 2000. A rapid assessment survey of exotic species in sheltered coastal waters. California Department of Fish \& Game, Sacramento

Floerl O, Pool TK, Inglis GJ (2004) Positive interactions between nonindigenous species facilitate transport by human vectors. Ecol Appl 14:1724-1736

Gallaway BJ, Lewbel GS (1981) The ecology of petroleum platforms in the northwestern Gulf of Mexico: a community profile, FWS 10BS-82/27, Open File Rept 82-03. US Fish \& Wildlife Service Office of Biology Services, Washington, DC

Grosholz E (2002) Ecological and evolutionary consequences of coastal invasions. Trends Ecol Evol 17:22-27

Hamzah BA (2003) International rules on decommissioning of offshore installations: some observations. Mar Policy 27: 339-348

Love MS, Schroeder DM, Nishimoto MM (2003) The ecological role of oil and gas platforms and natural outcrops on fishes in southern and central California: a synthesis of information. (OCS Study MMS 2003-032) US Department of the Interior, US Geological Survey, Seattle, WA

Page HM, Dugan JE, Dugan DS, Richards JB, Hubbard DM (1999) Effects of an offshore oil platform on the distribution and abundance of commercially important crab species. Mar Ecol Prog Ser 185:47-57

Pattengill CV, Semmens BX, Gittings SR (1997) Reef fish trophic structure of the Flower Gardens and Stetson Bay, NW Gulf of Mexico. Proc 8th Int Coral Reef Symp 1:1023-1028

Reggio VC (1989) Petroleum structures as artificial reefs: a compendium. In: Fourth International Conference on Artificial Habitats for Fisheries. Rigs-to-Reefs Special Session, Miami, FL, OCS Study/MMS 89-0021. US Dept Interior, Minerals Management Serv, Washington, DC

Rooker JR, Holt GJ, Pattengill CV, Dokken Q (1997) Fish

Editorial responsibility: Otto Kinne (Editor-in-Chief), Oldendorf/Luhe, Germany assemblages on artificial and natural reefs in the Flower Garden Banks National Marine Sanctuary, USA. Coral Reefs 16:83-92

Sammarco PW, Atchison AD, Boland GS (2004) Expansion of coral communities within the Northern Gulf of Mexico via offshore oil and gas platforms. Mar Ecol Prog Ser 280: 129-143

Sano M, Omori M, Taniguchi K (2003) Predator-prey systems of drifting seaweed communities off the Tohoku coast, northern Japan, as determined by feeding habit analysis of phytal animals. Fish Sci 69:260-268

Schmitz DC, Simberloff D (1997) Biological invasions: a growing threat. Issues Sci Technol 13:33-40

Schroeder DM, Love MS (2004) Ecological and political issues surrounding decommissioning of offshore oil facilities in the Southern California Bight. Ocean Coast Manag 47:21-48

Smith DL (1977) A guide to marine coastal plankton and marine invertebrate larvae. Kendall/Hunt, Dubuque, IA

Smith RI, Carlton JT (eds) (1975) Light's manual: intertidal invertebrates of the central California coast, 3rd edn. University of California Press, Berkeley, CA

Tierney TD, Kane F, Naughton O, Kennedy S, O'Konohoe P, Copley L, Jackson D (2004) On the occurrence of the caprellid amphipod, Caprella mutica Schurin 1935, in Ireland. Ir Nat J 27:437-439

Willis KJ, Cook EJ, Lozano-Fernandez M, Takeuchi I (2004) First record of the alien caprellid amphipod, Caprella mutica, for the UK. J Mar Biol Assoc UK 84:1027-1028

Wisely B (1958) The settling and some experimental reactions of a bryozoan larva, Watersipora cucullata (Busk). Aust J Mar Freshw Res 9:362-371

Wolfson A, Van Blaricom G, Davis N, Lewbel GS (1979) The marine life of an offshore oil platform. Mar Ecol Prog Ser 1: 81-89

Submitted: October 31, 2005; Accepted: March 23, 2006 Proofs received from author(s): October 5, 2006 